\title{
Nitrogen fertilization management in white oat using spectral indices ${ }^{1}$
}

\author{
José de Arruda Barbosa², Rogério Teixeira de Faria ${ }^{2}$, \\ Anderson Prates Coelho ${ }^{2}$, Alexandre Barcellos Dalri ${ }^{2}$, Luiz Fabiano Palaretti ${ }^{2}$
}

\section{ABSTRACT}

Remote sensing techniques have been considered a new technology in worldwide agriculture for diagnosing the plant nutritional demand. Fertilizer management efficiency is a goal to be achieved, and modern tools based on remote sensing are promising for monitoring the crop needs. This study aimed to evaluate the agronomic performance and relative economic return of white oat under nitrogen rates, as well as to verify whether the normalized difference vegetation index (NDVI) and leaf chlorophyll index (LCI) could be used for topdressing nitrogen fertilization management, in white oat. Treatments consisted of five topdressing nitrogen fertilization strategies: T1 - $160 \mathrm{~kg} \mathrm{ha}^{-1}$ (reference rate); T2 - $90 \mathrm{~kg} \mathrm{ha}^{-1}$ (recommended rate); T3 - $60 \mathrm{~kg} \mathrm{ha}^{-1}$ (economic rate); T4 $30 \mathrm{~kg} \mathrm{ha}^{-1}$ (when NDVI $<90 \%$ of T1); and T5 - $30 \mathrm{~kg} \mathrm{ha}^{-1}$ (when LCI $<90 \%$ of T1). The white oat did not respond to the topdressing nitrogen fertilization. Its temporal monitoring using spectral indices allowed dispensing the topdressing nitrogen fertilization without reducing the grain and biomass yields and the leaf nitrogen content, when compared to the recommended management ( $90 \mathrm{~kg} \mathrm{ha}^{-1}$ of $\mathrm{N}$ as topdressing), with no differences between the evaluated spectral indices. Thus, both the NDVI and LCI spectral indices are promising tools for the topdressing nitrogen fertilization management in the white oat crop.

KEYWORDS: Avena sativa L., leaf chlorophyll index, normalized difference vegetation index, precision agriculture.

\section{INTRODUCTION}

White oat (Avena sativa L.) is a cereal that can be consumed by humans or animals in several ways, as well as used in winter pasture growing and crop rotation systems as soil cover. In Brazil, its grown area increased $174 \%$, from $106,100 \mathrm{ha}^{-1}$, in 2007 , to 291,500 ha ${ }^{-1}$, in 2017 (Conab 2019).

\section{RESUMO}

Manejo da adubação nitrogenada em aveia-branca utilizando-se índices espectrais

Técnicas de sensoriamento remoto têm sido consideradas uma nova tecnologia na agricultura mundial para o diagnóstico da demanda nutricional das plantas. A eficiência no manejo de fertilizantes é uma meta a ser alcançada, e ferramentas modernas baseadas em sensoriamento remoto são promissoras para monitorar as necessidades das culturas. Objetivou-se avaliar o desempenho agronômico e o retorno econômico relativo de aveia-branca sob doses de nitrogênio, bem como verificar se o índice de vegetação por diferença normalizada (NDVI) e o índice de clorofila foliar (ICF) podem ser utilizados para o manejo da adubação nitrogenada em cobertura, em aveia-branca. Os tratamentos consistiram de cinco estratégias de manejo de adubação nitrogenada em cobertura: T1 - $160 \mathrm{~kg} \mathrm{ha}^{-1}$ (dose referência); T2 $90 \mathrm{~kg} \mathrm{ha}^{-1}$ (dose recomendada); T3 - $60 \mathrm{~kg} \mathrm{ha}^{-1}$ (dose econômica); T4 - $30 \mathrm{~kg} \mathrm{ha}^{-1}$ (quando NDVI < $90 \%$ de T1); e T5 - $30 \mathrm{~kg} \mathrm{ha}^{-1}$ (quando LCI $<90 \%$ de T1). Aaveia-branca não respondeu à adubação nitrogenada em cobertura. $\mathrm{O}$ seu monitoramento temporal por meio de índices espectrais permitiu dispensar a adubação nitrogenada em cobertura sem reduzir a produtividade de grãos e de biomassa e o teor de nitrogênio foliar, em relação ao manejo recomendado $\left(90 \mathrm{~kg} \mathrm{ha}^{-1} \mathrm{de}\right.$ $\mathrm{N}$ em cobertura), não existindo diferenças entre os índices espectrais avaliados. Assim, os índices espectrais NDVI e LCI são ferramentas promissoras para o manejo da fertilização nitrogenada em cobertura na cultura da aveia-branca.

PALAVRAS-CHAVE: Avena sativa L., índice de clorofila, índice de vegetação por diferença normalizada, agricultura de precisão.

In southeastern Brazil, the white oat growth is limited by water deficiency during the autumnwinter period; therefore, crops should be irrigated to obtain high grain yields. Fertilization is another requirement for increasing white oat yields, and nitrogen fertilizers are the most required ones. Thus, nitrogen fertilization must be properly managed, so that crops could express their yield potential.

\footnotetext{
${ }^{1}$ Received: Aug. 10, 2020. Accepted: Sep. 30, 2020. Published: Nov. 18, 2020. DOI: 10.1590/1983-40632020v5064924.

${ }^{2}$ Universidade Estadual Paulista, Faculdade de Ciências Agrárias e Veterinárias, Departamento de Engenharia e Ciências Exatas, Jaboticabal, SP, Brasil.E-mail/ORCID: josearruda777@gmail.com/0000-0002-7393-8839, rogerio.faria@unesp.br/ 0000-0002-1696-7940, anderson_100ssp@hotmail.com/0000-0003-2472-9704, alexandre.dalri@unesp.br/0000-0002-3122-1899, luiz.f.palaretti@unesp.br/0000-0001-5107-6038.
} 
As nitrogen losses in crops are of considerable importance, its efficient application and management are essential. This element has a high mobility in the soil profile, due to water solubility, leading to leaching and/or volatilization losses. Conventional nitrogen management is performed by applying fixed rates based on studies of crop response to different nutrient rates. Primavesi et al. (2004) pointed out that a conventional crop achieves its maximum forage yield using a rate of $160 \mathrm{~kg} \mathrm{ha}^{-1}$. However, for grain production, rates of $80 \mathrm{~kg} \mathrm{ha}^{-1}$ ensure a grain yield ranging from $3.2 \mathrm{Mg} \mathrm{ha}^{-1}$ (Kolchinski \& Schuch 2003 ) to $3.8 \mathrm{Mg} \mathrm{ha}^{-1}$ (Ceccon et al. 2004). Silva et al. (2016) found that the most economic rate to achieve a maximum white oat yield is $60 \mathrm{~kg} \mathrm{ha}^{-1}$. It is noteworthy that a fixed-rate fertilization method disregards the spatial variability of nutrients in the soil. Additionally, crop nutritional needs may vary with the sowing date, cultivation year, weather conditions, soil fertility, plant cultivar and irrigation management.

Although reliable, conventional methods are labor intensive, in terms of evaluating and quantifying nitrogen concentrations and respective plant nutritional demands. In these methods, plant samples were analyzed in the laboratory using, for example, the Kjeldahl method, which involves processes such as digestion, distillation and titration (Tedesco et al. 1995). Nowadays, new techniques are gaining space in agriculture to meet management and nutrition needs, according to each crop's demands and particularities. For instance, canopy spectralbased tools have been widely used, such as the normalized difference vegetation index (NDVI), which is the most well-known vegetation index. Among its other uses, NDVI may be applied as a proxy for crop nutritional status, since it is closely related to green color changes in crops (Zhao et al. 2018, Coelho et al. 2019).

Another real-time monitoring tool for nitrogen plant nutrition is the leaf chlorophyll index (LCI), which measures chlorophyll contents in leaf surfaces using a chlorophyll meter - ClorofiLOG (FAA 2008). The device uses photodiodes to emit light at three wavelengths, two within the red band, close to the peaks of each chlorophyll type $(\lambda=635$ and $660 \mathrm{~nm})$, and the other in the near-infrared $(\lambda=880 \mathrm{~nm})$, in addition to a sensor in the lower part receiving radiation transmitted through the leaf structure (Rouse et al. 1974).
Studies in the literature highlight that spectral indices such as NDVI and LCI are efficient due to the significant correlation between the green color intensity with chlorophyll content and leaf nitrogen concentrations, which enables estimating the plant nitrogen content on a real-time basis (Gil et al. 2002). Therefore, they can be used to predict nitrogen fertilizer demands, as opposed to destructive analyses (Maia et al. 2017, Coelho et al. 2018).

This study aimed to evaluate the agronomic performance and relative economic return of white oat under nitrogen rates, as well as to verify whether spectral indices such as NDVI and LCI could be used for topdressing nitrogen management in irrigated white oat grown in a high fertility soil.

\section{MATERIAL AND METHODS}

The experiment was conducted at the Universidade Estadual Paulista, in Jaboticabal, São Paulo state, Brazil (21 ${ }^{\circ} 14^{\prime} 44^{\prime \prime} \mathrm{S}, 48^{\circ} 17^{\prime} 00^{\prime \prime} \mathrm{W}$ and $545 \mathrm{~m}$ of mean altitude), in the winter of 2018 . According to the Köppen's classification, the local climate is Aw, which stands for subtropical with a mean annual temperature of $22{ }^{\circ} \mathrm{C}$, dry winters and mean annual precipitation of $1,425 \mathrm{~mm}$, concentrated in the summer (Alvares et al. 2013). The soil was classified as a clayey Eutrophic Red Latosol (Santos et al. 2013). Table 1 shows the soil physical and chemical attributes.

The experiment was carried out in a randomized block design, with four replications. Treatments consisted of five topdressing nitrogen $(\mathrm{N})$ fertilization managements: T1 - $160 \mathrm{~kg} \mathrm{ha}^{-1}$ (reference rate); T2 - $90 \mathrm{~kg} \mathrm{ha}^{-1}$ (recommended rate); T3 - $60 \mathrm{~kg} \mathrm{ha}^{-1}$ (economic rate); T4 - $60 \mathrm{~kg} \mathrm{ha}^{-1}$ (when NDVI $<90 \%$ of T1); and T5 - $60 \mathrm{~kg} \mathrm{ha}^{-1}$ (when LCI $<90 \%$ of $\mathrm{T} 1$ ). The $\mathrm{N}$ rate used in the reference treatment (T1) was based on recommendations by Primavesi et al. (2004), in order to avoid N deficiency in the white oat. Such a rate ensures that, during the crop cycle, plants will not show $\mathrm{N}$ deficiency, since it is the rate for maximum production in white oat (Primavesi et al. 2004). Thus, $\mathrm{T} 1$ was considered as a reference for the NDVI and LCI spectral indices. The $\mathrm{N}$ rate in $\mathrm{T} 2$ was that recommended for grain production (Primavesi et al. 2004, Escosteguy et al. 2014), while the rate in T3 was based on Silva et al. (2016), for white oat at economic production.

The experimental plots were $5 \mathrm{~m}$ long by $2.4 \mathrm{~m}$ wide, with a total experimental area of $240 \mathrm{~m}^{2}$. The 
Table 1. Physical and chemical attributes of the soil in the experimental area.

\begin{tabular}{|c|c|c|c|c|c|c|c|c|c|c|c|c|}
\hline $\begin{array}{l}\text { Depth } \\
\text { m }\end{array}$ & $\begin{array}{c}\mathrm{Sd}^{*} \\
\mathrm{~g} \mathrm{~cm}^{-3}\end{array}$ & $\begin{array}{l}\theta^{*} \mathrm{FC}^{*} \\
\mathrm{~m}^{3} \mathrm{~m}^{-3}\end{array}$ & \multicolumn{2}{|l|}{$\begin{array}{c}\theta^{*} \\
\text { PWP* }\end{array}$} & \multicolumn{2}{|c|}{ Sand } & \multicolumn{2}{|c|}{$\begin{array}{r}\text { Clay } \\
-\mathrm{g} \mathrm{kg}^{-1}\end{array}$} & \multicolumn{2}{|c|}{ Silt } & \multicolumn{2}{|c|}{$\begin{array}{c}\text { Soil } \\
\text { texture }\end{array}$} \\
\hline $0.00-0.20$ & 1.45 & 0.45 & 0.33 & & 310 & & & & & & & \\
\hline $0.20-0.40$ & 1.49 & 0.41 & 0.30 & & 270 & & & 0 & & & & \\
\hline $\begin{array}{c}\text { Depth } \\
\text { m }\end{array}$ & $\begin{array}{c}\mathrm{pH} \\
\mathrm{CaCl}_{2}\end{array}$ & $\begin{array}{c}\mathrm{OM} \\
\mathrm{g} \mathrm{dm}^{-3}\end{array}$ & $\begin{array}{c}\mathrm{P}_{\text {resin }} \\
\mathrm{mg} \mathrm{dm}^{-3}\end{array}$ & $\mathrm{~S}$ & $\mathrm{H}+\mathrm{Al}$ & $\mathrm{Al}$ & $\begin{array}{c}\mathrm{K} \\
-\mathrm{m}\end{array}$ & $\begin{array}{c}\mathrm{Ca} \\
\mathrm{d}_{\mathrm{c}} \mathrm{dm}^{-}\end{array}$ & $\mathrm{Mg}$ & SB & CEC & $\begin{array}{c}\mathrm{BS} \\
\%\end{array}$ \\
\hline $0.00-0.20$ & 5.6 & 40 & 67 & 5 & 21 & 1 & 3.4 & 36 & 13 & 52.7 & 73.9 & 71 \\
\hline $0.20-0.40$ & 5.8 & 40 & 68 & 5 & 20 & 1 & 3.2 & 36 & 11 & 50.3 & 70.4 & 71 \\
\hline $\begin{array}{c}\text { Depth } \\
\text { m }\end{array}$ & & & & $\mathrm{Cu}$ & $-\mathrm{mg} \mathrm{dn}$ & & e & & & & $\mathrm{Zn}$ & \\
\hline $0.00-0.20$ & & & & 6.7 & & & & & & & 5.6 & \\
\hline $0.20-0.40$ & & & & 5.5 & & & & & & & 4.6 & \\
\hline
\end{tabular}

first $0.40 \mathrm{~m}$ on each side of the plots was considered as borderline, resulting in a useful area of $8.64 \mathrm{~m}^{2}$.

Both spectral indices were weekly measured from 23 days after emergence (DAE) until $58 \mathrm{DAE}$, comprising the phenological stages between tillering (3) and beginning of flowering (10.5), according to Large (1954). If NDVI and LCI were between 90 and $95 \%$ of the reference treatment (T1), measurements were performed again 3 days later, and fertilizer was applied when the indices were below $90 \%$.

The fertilization in the reference treatment (T1) was divided into two equal applications, the first at 15 DAE ( $80 \mathrm{~kg} \mathrm{ha}^{-1}$ of $\left.\mathrm{N}\right)$ and the second in conjunction with those of the T2 and T3 treatments, which were applied at $27 \mathrm{DAE}$, as recommended for white oat (Escosteguy et al. 2014). T4 and T5 were referenced to $90 \%$ of the NDVI and LCI of T1, respectively. Fertilization at $\mathrm{T} 1$ was applied earlier than at the other treatments, so that the crop could absorb N.

The NDVI was measured using a portable sensor (GreenSeeker ${ }^{\mathrm{TM}}$ ). This is an active sensor that automatically generates NDVI values from the red band $(650 \mathrm{~nm})$ and near-infrared $(770 \mathrm{~nm})$ spectral responses. The device was directed to the center of each plot, $0.5 \mathrm{~m}$ above the plant canopy. Each plot had a sampled area of $5.9 \mathrm{~m}^{2}$, which corresponded to a $9.8-\mathrm{m}$ displacement of the $0.6-\mathrm{m}$ useful width captured by the sensor, making 20 to 30 NDVI measurements per repetition. The LCI was measured by a Clorofilog Falker. Measurements were taken in the first expanded leaf of ten plants per plot (Coelho et al. 2018), in the center of each leaf.

After the NDVI and LCI readings, the averages were estimated for each treatment. When the average of the NDVI (T3) or LCI (T4) was below $90 \%$ of the value read in the reference treatment (T1), fertilization was performed on the day after the evaluation, at a rate of $30 \mathrm{~kg} \mathrm{ha}^{1}$ of $\mathrm{N}$ (Maia et al. 2017). We used the $90 \%$ index recommended by Maia et al. (2017), that defines critical indices for crops. When nutrient contents and other factors are above $90 \%$ of the maximum value, there are no significant increases in the growth and yield of agricultural crops (Cantarella et al. 1996). The need for $\mathrm{N}$ fertilization in white oat using spectral indices was monitored until the beginning of flowering. Thus, more than $30 \mathrm{~kg} \mathrm{ha}^{-1}$ of $\mathrm{N}$ may be required throughout the crop cycle to supply the plant needs.

The experimental area was previously cultivated with Urochloa brizantha cv. Marandu, from 2013 to 2017. Between May and August 2017, white oat was grown and, then, it was left fallow until the winter of 2018. The experiment was sown on May 2, 2018, using $80 \mathrm{~kg} \mathrm{ha}^{-1}$ of white oat seeds of the IAC 7 cultivar, at $0.17 \mathrm{~m}$ row spacing. This genotype has the following agronomic traits: height of $0.90-1.20 \mathrm{~m}$, early cycle (90-120 days), grain yield up to $4 \mathrm{Mg} \mathrm{ha}^{-1}$ and straw yield up to $15 \mathrm{Mg} \mathrm{ha}^{-1}$ (IAC 2020).

The soil was limed 30 days before sowing, at a rate of $1.5 \mathrm{Mg} \mathrm{ha}^{-1}$ of limestone. Base fertilization was applied using 20, 160 and $80 \mathrm{~kg} \mathrm{ha}^{-1}$ of $\mathrm{N}, \mathrm{P}_{2} \mathrm{O}_{5}$ and $\mathrm{K}_{2} \mathrm{O}$, using urea, simple superphosphate and potassium chloride as sources, respectively. Pests, diseases and weeds were controlled according to the guidelines for the crop.

The experiment was uniformly irrigated with sprinklers spaced 12 × $6 \mathrm{~m}$ (lines x sprinklers). The 
plots were irrigated after readily available water was depleted (about $23 \mathrm{~mm}$ ), calculated to be $50 \%$ of the available water capacity (AWC), which was estimated as the product between the root effective depth of the white oat $(40 \mathrm{~cm})$ and the available water that was obtained by the difference between the moisture in the field capacity and permanent wilting point (Table 1). The crop water consumption was calculated according to the FAO-56 method, as the product between the crop coefficient $(\mathrm{Kc})$ and the reference evapotranspiration (Allen et al. 1998). The used crop coefficient (Kc) values were $0.30,0.75,1.15$ and 0.25 , corresponding to soil cover fractions of up to $10 \%$, between 10 and $80 \%, 80$ and $100 \%$, and physiological maturity, respectively.

Figure 1A displays the maximum, minimum and average daily temperatures, whose averages during the experimental period were 28.2, 14.2 and $20.6{ }^{\circ} \mathrm{C}$, respectively. The rainfall and accumulated ETc for the white oat cycle were 50.9 and $170.6 \mathrm{~mm}$, respectively (Figure 1B). The total irrigation depth during the crop cycle was $140 \mathrm{~mm}$.

Besides the NDVI and LCI, the leaf N contents were determined by the Kjeldahl method (Tedesco et al. 1995), using 10 leaves per plot. The measurements were made in the following stages: onset of the pseudostem (4), rubbery (8), appearance of flag leaf sheath (10) and kernel watery ripe (10.5.4) (Large 1954). The leaves were collected at $27,43,58$ and 71 days after seedling emergence, sampling the first expanded leaves.

The grain and biomass yields were also determined. Grains were weighed after harvesting a $1.90-\mathrm{m}^{2}$ area per plot ( 8 rows of $1.40 \mathrm{~m}$ long) and standardizing the moisture levels to $14 \%$. The total dry matter yield was estimated using a plant shoot sampled from the useful area (4 rows of $1.40 \mathrm{~m}$ long $=0.95 \mathrm{~m}^{2}$ ), which was then taken to a forced circulation oven to be dried at $65^{\circ} \mathrm{C}$, for 72 hours, and weighed. All plants collected for the total dry matter yield determination were weighed after harvested. A sample of the total was taken to a forced circulation oven to be dried.

The relative economic return was calculated by the following equation: RER $=($ Psc $x G Y)-$ (PN x R), in which: RER is the relative economic return $\left(\mathrm{R} \$ \mathrm{ha}^{-1}\right)$; Psc the price of $1 \mathrm{~kg}$ of white oat on May 05, 2019 (R\$ $\left.0.3865 \mathrm{~kg}^{-1}\right)$; GY the grain yield $\left(\mathrm{kg} \mathrm{ha}^{-1}\right)$; PN the price of $1 \mathrm{~kg}$ of $\mathrm{N}$ from urea on May 05, $2019\left(\mathrm{R} \$ 3.26 \mathrm{~kg}^{-1}\right)$; and $\mathrm{R}$ the applied $\mathrm{N}$ rate $\left(\mathrm{kg} \mathrm{ha}^{-1}\right)$.

Data underwent an analysis of variance ( $\mathrm{F}$ test) at a probability of $5 \%$. If necessary, the means were compared by the Tukey test at a probability of $5 \%$.

\section{RESULTS AND DISCUSSION}

The treatments showed no differences for grain and biomass yield and leaf $\mathrm{N}$ content throughout the entire white oat cycle (Table 2).

The white oat $\mathrm{N}$ fertilization was monitored using spectral indices from 23 to $58 \mathrm{DAE}$. If compared to the reference treatment (T1), no treatment with $\mathrm{N}$ fertilization, as a function of spectral indices (T4 and T5), showed NDVI and LCI below $90 \%$ (Figure 2). Thus, these treatments received no topdressing $\mathrm{N}$, since measurements indicated the same canopy spectral response as that of the reference treatment, which received $160 \mathrm{~kg} \mathrm{ha}^{-1}$ of $\mathrm{N}$.

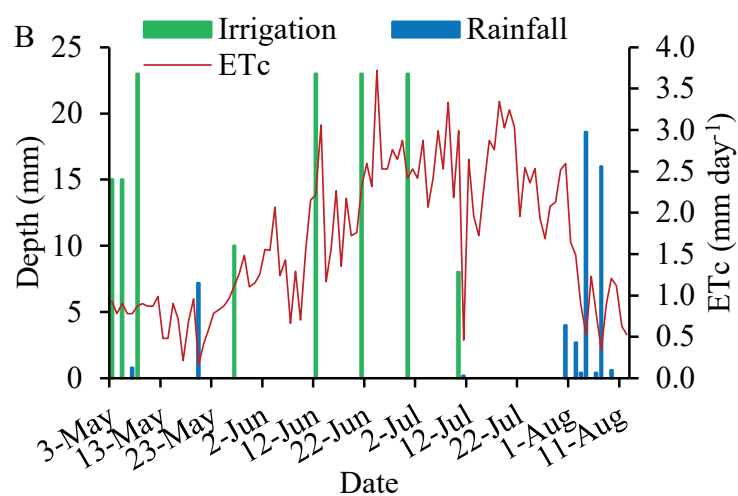

Figure 1. Maximum, minimum and mean daily temperatures (A), precipitation, ETc and accumulated daily irrigation depth (B), from May 02 to August 11, 2018. 
Table 2. Summary of the analysis of variance for grain and biomass yield and leaf $\mathrm{N}$ content throughout the white oat cycle, under topdressing nitrogen managements.

\begin{tabular}{|c|c|c|c|}
\hline \multirow{2}{*}{ Parameter } & \multicolumn{2}{|c|}{ Treatment } & \multirow{2}{*}{$\begin{array}{c}\text { CV } \\
\% \\
\end{array}$} \\
\hline & $\mathrm{F}$ & p-value & \\
\hline Grain yield & 2.07 & 0.148 & 10.75 \\
\hline Biomass yield & 1.20 & 0.360 & 42.87 \\
\hline Nitrogen leaf content - 27 DAE (4) & 0.43 & 0.781 & 8.15 \\
\hline Nitrogen leaf content - 43 DAE (8) & 0.27 & 0.893 & 12.25 \\
\hline Nitrogen leaf content - 58 DAE (10) & 2.03 & 0.154 & 6.77 \\
\hline Nitrogen leaf content - 71 DAE (10.5.4) & 1.21 & 0.358 & 7.74 \\
\hline
\end{tabular}

p-value: probability of occurrence of the null hypothesis (Ho); CV: coefficient of variation; DAE: days after emergence. The numbers inside the parentheses indicate the white oat phenological stage.

Figure 3 shows the averages for grain and biomass yield. The results indicate that the adopted $\mathrm{N}$ managements were similar, confirming that the treatments were similar, in terms of plant nutritional status, even in treatments without $\mathrm{N}$ fertilization and monitored by NDVI and LCI. Therefore, the NDVI

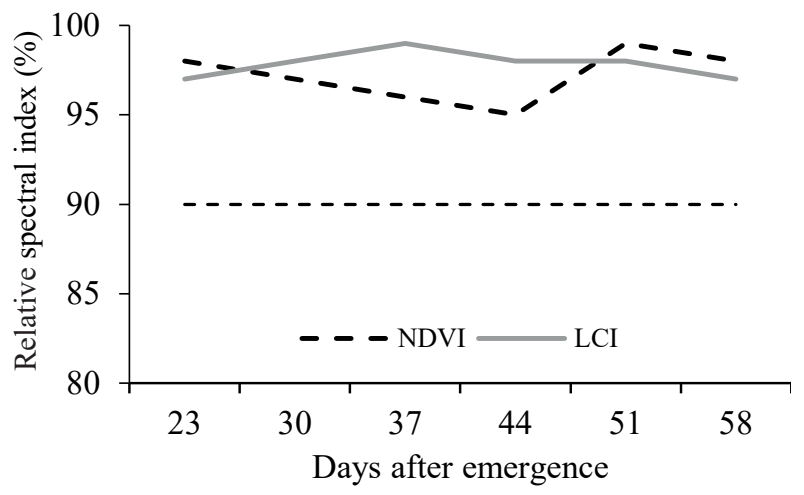

Figure 2. Changes in the normalized difference vegetation index - NDVI (T4) and leaf chlorophyll index - LCI (T5), in relation to the reference treatment ( $\mathrm{T} 1$ $160 \mathrm{~kg} \mathrm{ha}^{-1}$ ).

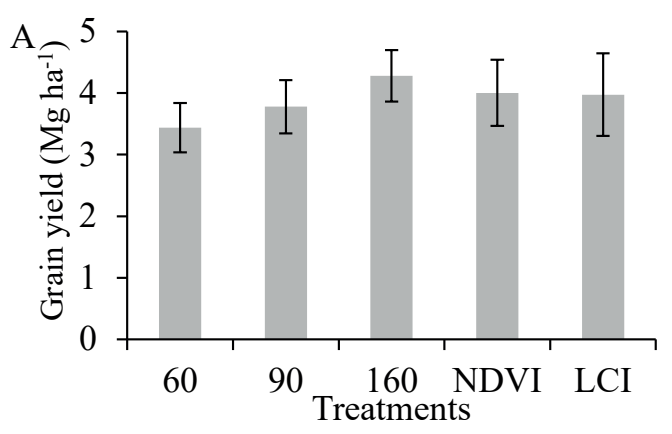

and LCI were compatible with the plant responses, as a function of the $\mathrm{N}$ management strategy. Thus, this method is reliable to indicate the crop nutritional status.

Grain yield ranged from 3.5 to $4.2 \mathrm{Mg} \mathrm{ha}^{-1}$ (Figure 3a) and biomass yield between 8.3 and $10 \mathrm{Mg} \mathrm{ha}^{-1}$ (Figure 3b). These yield variables are important, since white oat is grown for a dualpurpose use, grain and forage for animal feeding. For this reason, topdressing $\mathrm{N}$ is suitable for white oat regardless of the production purpose, since it showed statistically equal values $(p>0.05)$ to the other treatments for grain and biomass yield, even when compared to the reference treatment (T1).

During the experimental period, the NDVI (Figure 4A) and LCI (Figure 4B) readings were close to the readings of the optical sensors (T4 - NDVI and T5 - LCI), which did not receive fertilization, and the reference treatment (T1 - $\left.160 \mathrm{~kg} \mathrm{ha}^{-1}\right)$, which received the highest $\mathrm{N}$ rate. Given this similarity in spectral emission, it can be assumed that the plant nutritional status was also similar, especially in terms of $\mathrm{N}$ content, as already reported in other studies (Coelho et al. 2018, Zhao et al. 2018).

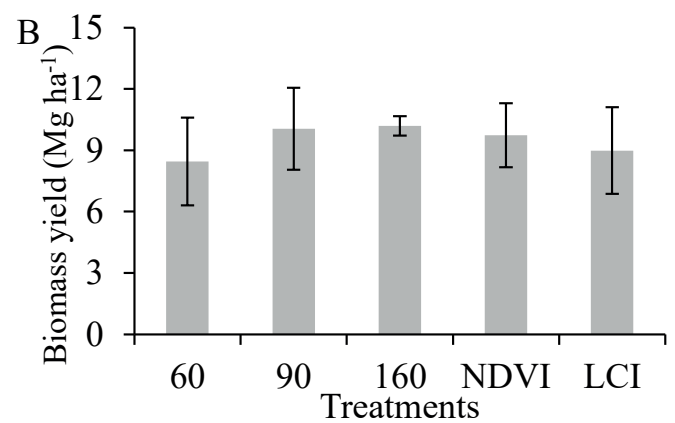

Figure 3. Averages for grain (A) and biomass (B) yield, for topdressing nitrogen treatments in white oat (T1 - $160 \mathrm{~kg}$ ha-1; T2 $90 \mathrm{~kg} \mathrm{ha}^{-1}$; T3 - $60 \mathrm{~kg} \mathrm{ha}^{-1}$; T4 - NDVI; T5 - LCI). Bars indicate the standard deviation of each treatment. NDVI - normalized difference vegetation index; LCI - leaf chlorophyll index. 
The treatments showed no difference for leaf $\mathrm{N}$ content during the crop cycle (Figure 5A).

A maximum value was found at $58 \mathrm{DAE}$ (Figure 5C), when plants were at the 10.5.4 phenological stage (end of flowering and watery grain formation). Cantarella et al. (1996) stated that suitable $\mathrm{N}$ leaf contents for this crop range from 20 to $30 \mathrm{~g} \mathrm{~kg}^{-1}$. Given that, no treatment presented $\mathrm{N}$ content lower than the minimum limit established $\left(20 \mathrm{~g} \mathrm{~kg}^{-1}\right)$ for white oat at the 10.5.4 stage (58 DAE). In other words, no $\mathrm{N}$ deficiency was observed in treatments under NDVI and LCI management.

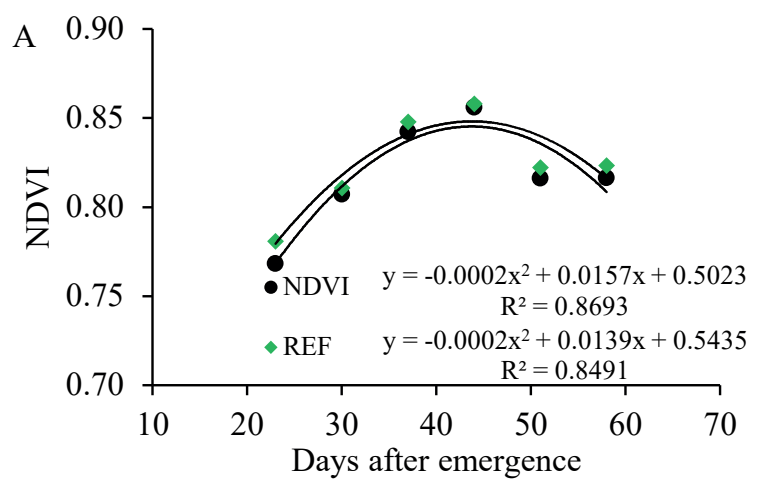

The white oat relative economic returns were significantly different $(\mathrm{p}<0.05)$, as a function of topdressing N (Figure 6). Fertilizations guided by spectral indexes (T4 and T5) had an average relative economic return $26 \%$ higher than the other treatments (T1, T2 and T3).

Similarities in grain and biomass yield among the treatments may be justified by the low response of white oat to $\mathrm{N}$ fertilization in irrigated and high fertility conditions (Coelho et al. 2019). In a place near the study area, Coelho et al. (2019) found no significant differences for white oat biomass

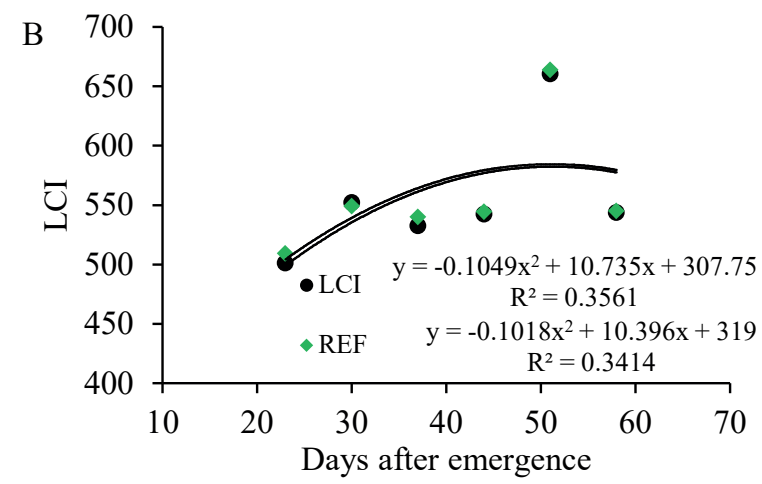

Figure 4. Spectral index evolution (A - NDVI; B - LCI) for topdressing nitrogen treatments in white oat, in relation to the reference treatment $(\mathrm{REF})\left(\mathrm{T} 1=160 \mathrm{~kg} \mathrm{ha}^{-1}\right.$ of N). NDVI - normalized difference vegetation index; LCI - leaf chlorophyll index.
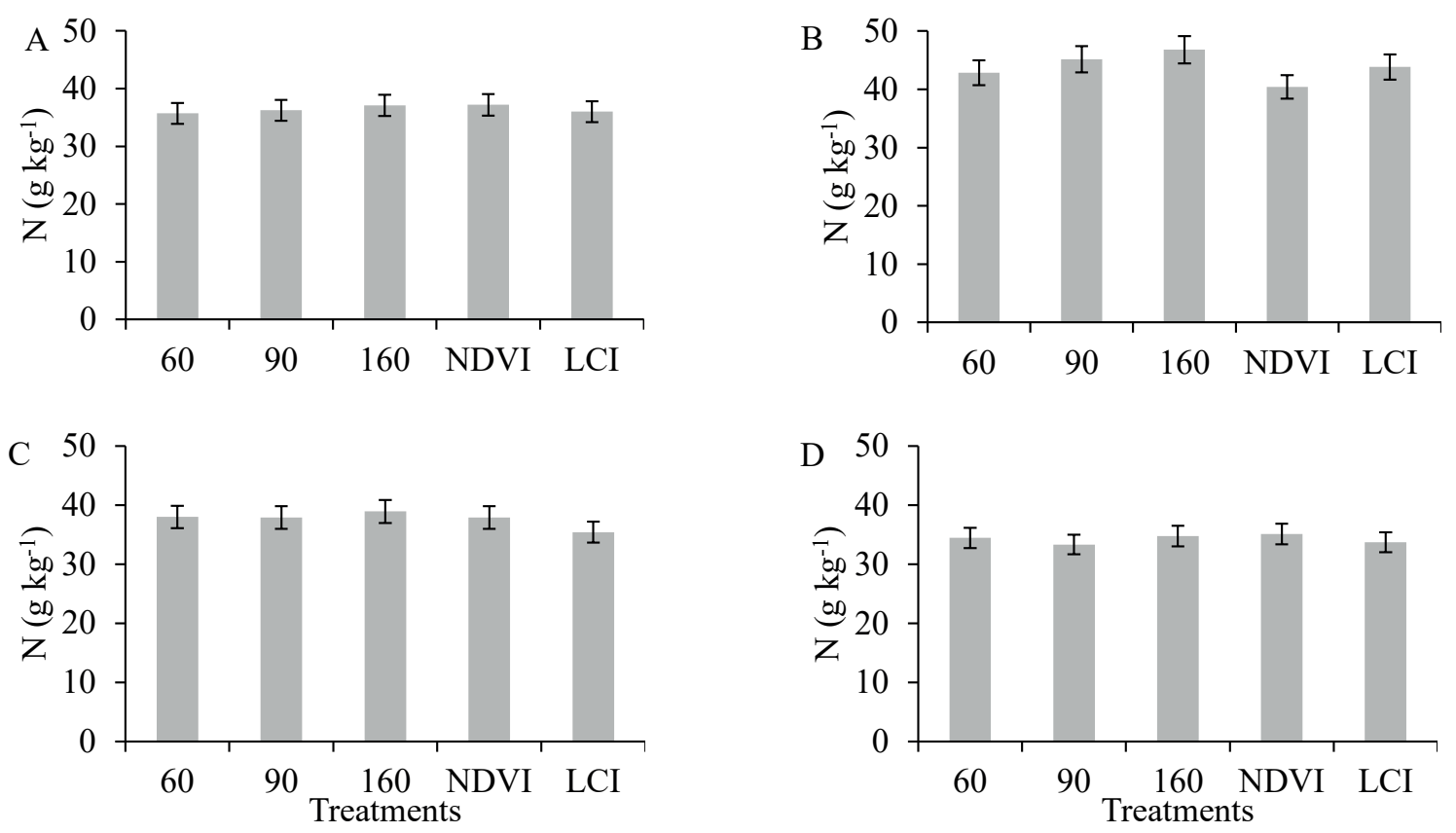

Figure 5. Nitrogen $(\mathrm{N})$ leaf content of the treatments under nitrogen fertilization in white oat topping at 27 (A), 43 (B), 58 (C) and 71 (D) days after sowing the crop. Bars indicate the standard deviation of each treatment. NDVI - normalized difference vegetation index; LCI - leaf chlorophyll index. 


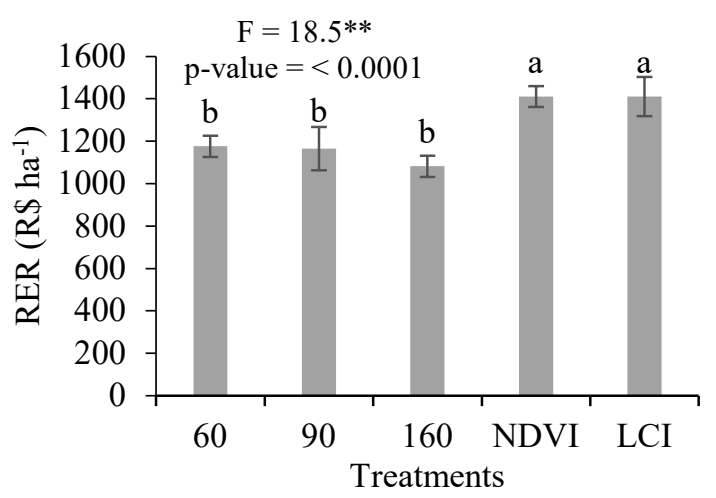

Figure 6. White oat relative economic return (RER), as a function of nitrogen topdressing management (T1 - $160 \mathrm{~kg} \mathrm{ha}^{-1}$; T2 - $90 \mathrm{~kg} \mathrm{ha}^{-1}$; T3 - $60 \mathrm{~kg} \mathrm{ha}^{-1}$; T4 - NDVI; T5 - LCI). Bars indicate the standard deviation of each treatment. NDVI - normalized difference vegetation index; LCI leaf chlorophyll index.

yield when rates between 10 and $95 \mathrm{~kg} \mathrm{ha}^{-1}$ of $\mathrm{N}$ were applied. The authors also noticed that the highest averages for grain yield were observed at a topdressing $\mathrm{N}$ rate of $29 \mathrm{~kg} \mathrm{ha}^{-1}$, hence this crop has a low response to $\mathrm{N}$ fertilization in high-fertility soils.

Other studies carried out near the present study area also showed a low crop response of other crops to $\mathrm{N}$ fertilization to increase yield, especially common bean (Flôres et al. 2017) and corn (Amaral et al. 2018). These results may be justified by the fact that the soil in the experimental area has only $4 \%$ of organic matter $\left(40 \mathrm{~g} \mathrm{dm}^{-3}\right)$, high levels of phosphorus and exchangeable bases, and base saturation above $70 \%$ to a depth of $0.40 \mathrm{~m}$ (Table 1). Thus, the $\mathrm{N}$ supply to white oat was due to the amount of nutrient applied via mineral fertilizers at sowing $\left(20 \mathrm{~kg} \mathrm{ha}^{-1}\right)$ and mineralization of soil organic matter. Coelho et al. (2020), studying the $\mathrm{N}$ absorption gait in white oat grown in an experimental area near the present study area, observed a maximum accumulation of $246 \mathrm{~kg} \mathrm{ha}^{-1}$ of $\mathrm{N}$. The authors noticed that the soil could supply at least $126 \mathrm{~kg} \mathrm{ha}^{-1}$ of $\mathrm{N}$, since combined $\mathrm{N}$ fertilization at planting and topdressing may have provided a maximum of $120 \mathrm{~kg} \mathrm{ha}^{-1}$ of $\mathrm{N}$. That may explain the high capacity of the soil in the present study area to supply $\mathrm{N}$ to the white oat.

These results can be confirmed by the leaf $\mathrm{N}$ contents throughout the crop cycle (Figure 6). All N managements showed no differences in the $\mathrm{N}$ leaf contents, in the evaluated periods. Also regarding the leaf diagnosis (Figure 6), the $\mathrm{N}$ levels were above the range considered ideal for white oat, which is from 20 to $30 \mathrm{~g} \mathrm{~kg}^{-1}$ (Cantarella et al. 1996), thus characterizing a luxury consumption.

The high soil fertility in the study area may be explained by the history of the crop cultivation. During four years (2013 to 2017), it was cultivated with $U$. brizantha, which is a grass with a high biomass production over the year. This promoted increases in contents of soil organic matter and other nutrients due to its ability to cycle soil nutrients (Gopalakrishnan et al. 2009). Moreover, species of the Urochloa genus are reported to release exudates from their roots, which reduce nitrification and hence $\mathrm{N}$ losses by leaching in agricultural areas (Gopalakrishnan et al. 2009). All the above explain the high soil fertility in the experimental area and the low response of white oat to $\mathrm{N}$ fertilization.

The use of LCI and NDVI for N fertilization management in crops is based on the correlation between their readings with plant nutritional status, especially N (Schlichting et al. 2015, Rhezali \& Lahlali 2017). Thus, the temporal monitoring of such indices help to identify the best time to apply N. This allows reducing crop-specific recommended $\mathrm{N}$ rates without affecting yield by increasing the fertilizer efficiency (Maia et al. 2017). Maia et al. (2017), studying changes in topdressing $\mathrm{N}$ management in common bean, as a function of LCI observations, claimed that the grain yield can be maintained, when comparing the recommended rates with no $\mathrm{N}$ application. This was also observed in our study, since, regardless of the rate, both the grain and biomass yields were similar among the treatments.

Unlike the standard recommendations for fertilization, the use of spectral indices to manage $\mathrm{N}$ fertilization has a high specificity. This is because a reference is created for all conditions using benchmark areas, that is, crops without nutritional deficiencies throughout the cycle, given the application of high $\mathrm{N}$ doses. Thus, the $\mathrm{N}$ fertilization management, as a function of spectral indices, is specific for factors such as cultivar, weather conditions and crop growth.

In this sense, unfavorable climatic conditions may reduce the growth of a given crop, directly interfering with its demands for factors such as water and nutrients. Standard recommendations may overestimate the amount of nutrients required by crops without significant yield increases. Here we noted that high temperatures before the white oat flowering (Figure 1) hindered the plant growth. Fortnightly averages of maximum temperatures 
between 0 and $60 \mathrm{DAE}$ (before flowering) were 29.9, 26.9, 28.0 and $28.7^{\circ} \mathrm{C}$, which are considered high for white oat. According to Ugarte et al. (2007), high temperatures before the anthesis of winter cereals are harmful, and the ideal maximum temperature limit for this period is $28^{\circ} \mathrm{C}$. While simulating the growth cycle of white oat, as a function of photoperiod and temperature, Mantai et al. (2017) observed that the optimal temperatures between emergence and anthesis, and from anthesis to maturation, were 22 and $25{ }^{\circ} \mathrm{C}$, respectively. In this sense, white oat is more sensitive to high temperatures before anthesis. This is because high temperatures during the tillering of winter cereals reduce the final crop population, thus affecting yield (Thorne \& Wood 1987).

The lower growth and yield of white oat in 2018 , in relation to agricultural years with milder temperatures, can be compared to results by Coelho et al. (2019). These authors evaluated the agronomic performance of white oat in an area close to that of the present study, with the same soil type, in a crop year with milder temperatures (2017). They observed a maximum yield of up to $5,800 \mathrm{~kg} \mathrm{ha}^{-1}$, which is approximately $1,600 \mathrm{~kg} \mathrm{ha}^{-1}$ higher than that in the present study. This fact confirms the lower growth of white oat in 2018, directly interfering with plant demand for nutrients.

The standard recommendation $\left(90 \mathrm{~kg} \mathrm{ha}^{-1}\right)$ for topdressing $\mathrm{N}$ did not promote yield increases, if compared to the lack of topdressing N (T4 and T5). Besides not affecting the yield, managing the topdressing $\mathrm{N}$ in white oat using spectral indices promoted a relative economic return $21 \%$ higher (Figure 6) than the recommended rate (T2) and 20\% higher than the economic rate (T3) (Silva et al. 2016).

The use of spectral indices to evaluate and monitor white oat reduced the $\mathrm{N}$ fertilizer costs by decreasing fertilizations and wastes. Moreover, such tools can assist in preserving the environment, avoiding unnecessary applications that would increase the soil $\mathrm{N}$ content.

\section{CONCLUSION}

Topdressing nitrogen $(\mathrm{N})$ in white oat can be managed using the normalized difference vegetation index (NDVI) and leaf chlorophyll index (LCI) without differences in crop performance under the studied rates. The temporal monitoring of white oat by these spectral indices allows dispensing topdressing $\mathrm{N}$ fertilizations without reducing the crop performance, if compared to the recommended rate (90 kg ha-1 of $\mathrm{N}$ as topdressing). There were no differences between the studied spectral indices. Thus, both NDVI and LCI are promising tools for managing topdressing $\mathrm{N}$ in white oat.

\section{ACKNOWLEDGMENTS}

This study was supported by the Coordenação de Aperfeiçoamento de Pessoal de Nível Superior (Capes), with a Masters scholarship granted to the first author.

\section{REFERENCES}

ALLEN, R. G.; PEREIRA, L. S.; RAES, D.; SMITH, M. Crop evapotranspiration: guidelines for computing crop water requirements. Rome: FAO, 1998. (Irrigation and drainage paper, 56).

ALVARES, C. A.; STAPE, J. L.; SENTELHAS, P. C.; GONÇALVES, J. L. M.; SPAROVEK, G. Köppen's climate classification map for Brazil. Meteorologische Zeitschrift, v. 22, n. 6, p. 711-728, 2013.

AMARAL, C. B.; OLIVEIRA, G. H. F.; MÔRO, G. $\mathrm{V}$. Phenotyping open-pollinated maize varieties for environments with low nitrogen availability. Archives of Agronomy and Soil Science, v. 64, n. 10, p. 1465-1472, 2018.

CANTARELLA, H.; RAIJ, B. V.; CAMARGO, C. E. O. Cereais. In: RAIJ, B. V.; CANTARELLA, H.; QUAGGIO, J. A.; FURLANI, A. M. C. Recomendações de adubação e calagem para o estado de São Paulo. Campinas: Instituto Agronômico, 1996. p. 45-47.

CECCON, G.; GRASSI FILHO, H.; BICUDO, S. J. White oat (Avena sativa L.) grains yield using different plant densities and nitrogen levels. Ciência Rural, v. 34, n. 6, p. 1723-1729, 2004.

COELHO, A. P.; FARIA, R. T.; BARBOSA, A. M. S.; DALRI, A. B.; ROSALEN, D. L. Agronomic performance of white oat cultivated under fertigation with treated sewage effluent and definition of critical limits of normalized difference vegetation index. Bragantia, v. 78, n. 4, p. 553-563, 2019.

COELHO, A. P.; FARIA, R. T.; LEAL, F. T.; BARBOSA, J. A.; LEMOS, L. B. Biomass and nitrogen accumulation in white oat (Avena sativa L.) under water deficit. Revista Ceres, v. 67, n. 1, p. 1-8, 2020.

COELHO,A.P.; FARIA, R. T.; SALRI,A.B.; PALARETTI, L. F.; ZANINI, J. R. Clorofilômetro portátil como forma de manejo da irrigação e adubação nitrogenada em aveia- 
branca. Revista Brasileira de Agricultura Irrigada, v. 12, n. 2, p. 2542-2553, 2018.

\section{COMPANHIA NACIONAL DE ABASTECIMENTO} (Conab). Acompanhamento da safra brasileira: grãos: safra 2018/19. 2019. Available at: https://www.conab.gov. br/info-agro/safras/graos/monitoramento-agricola. Access on: May 15, 2019.

EScOSTEGUY, P. A. V.; FONTOURA, S. M. V.; CARVALHO, I. Q. Fertilidade do solo, calagem e adubação. In: LÂNGARO, N. C.; CARVALHO, I. Q. (ed.). Indicações técnicas para a cultura da aveia. Passo Fundo: Fundação ABC, 2014. p. 24-43.

FALKER AGRICULTURAL AUTOMATION (FAA). Manual of the chlorophyll-content electronic meter (Chlorofilog/CFL 1030). 2008. Available at: http://www. falker.com.br/produto_download.php? id $=4$. Access on: May 13, 2019.

FLÔRES, J. A.; AMARAL, C. B.; PINTO, C. C.; MINGOTTE, F. L. C.; LEMOS, L. B. Agronomic and qualitative traits of common bean as a function of the straw and nitrogen fertilization. Pesquisa Agropecuária Tropical, v. 47, n. 2, p. 195-201, 2017.

GIL, P. T.; FONTES, P. C. R.; CECON, P. R.; FERREIRA, F. A. Índice SPAD para o diagnóstico do estado de nitrogênio e para o prognóstico da produtividade da batata. Horticultura Brasileira, v. 20, n. 4, p. 611-615, 2002.

GOPALAKRISHNAN, S.; WATANABE, T.; PEARSE, S. J.; ITO, O.; HOSSAIN, Z. A.; SUBBARAO, G. V. Biological nitrification inhibition by Brachiaria humidicola roots varies with soil type and inhibits nitrifying bacteria, but not other major soil microorganisms. Soil Science and Plant Nutrition, v. 55, n. 5, p. 725-733, 2009.

INSTITUTO AGRONÔMICO DE CAMPINAS (IAC). Aveia branca IAC 7. 2020. Available at: http://www. cdrs.sp.gov.br/portal/themes/unify/arquivos/produtos-eservicos/AVEIA-BRANCA-IAC7.pdf. Access on: Sep. 30, 2020.

KOLCHINSKI, E. M.; SCHUCH, L. O. B. Eficiência no uso do nitrogênio por cultivares de aveia-branca de acordo com a adubação nitrogenada. Revista Brasileira de Ciência do Solo, v. 27, n. 6, p. 1033-1038, 2003.

LARGE, E. C. Growth stages in cereals illustration of the Feekes scale. Plant Pathology, v. 3, n. 4, p. 128-129, 1954.

MAIA, S. C. M.; SORATTO, R. P.; LIEBE, S. M.; ALMEIDA, A. Q. D. Criteria for topdressing nitrogen application to common bean using chlorophyll meter. Pesquisa Agropecuária Brasileira, v. 52, n. 7, p. 512520, 2017.

MANTAI, R. D.; SILVA, J. A.; MAROLLI,A.; MAMANN, A. T.; SAWICKI, S.; KRUGER, C. A. Simulation of oat development cycle by photoperiod and temperature. Revista Brasileira de Engenharia Agrícola e Ambiental, v. 21, n. 1, p. 3-8, 2017.

PRIMAVESI, A. C.; PRIMAVESI, O.; CANTARELLA, H.; GODOY, R. Resposta da aveia branca à adubação em Latossolo Vermelho-Amarelo em dois sistemas de plantio. Revista Brasileira de Zootecnia, v. 33, n. 1, p. 79-86, 2004.

RHEZALI, A.; LAHLALI, R. Nitrogen (N) mineral nutrition and imaging sensors for determining $\mathrm{N}$ status and requirements of maize. Journal of Imaging, v. 3, n. 4, p. 51-60, 2017.

ROUSE, J. W.; HASS, R. H.; DEERING, D. W.; SCHELL, J. A.; HARLAN, J. C. Monitoring vegetation systems in the great plains with ERTS. In: EARTH RESOURCES TECHNOLOGY SATELLITE-1 SYMPOSIUM, 3., 1974, Washington, DC. Proceedings... Washington, DC: NASA, 1974. p. 307-317.

SANTOS, H. G.; JACOMINE, P. K. T.; ANJOS, L. H. C.; OLIVEIRA, V. A.; LUMBRERAS, J. F.; COELHO, M. R.; CUNHA, T. J. F. Sistema brasileiro de classificação de solo. 3 ed. Brasília, DF: Embrapa, 2013.

SCHLICHTING, A. F.; BOMFIM-SILVA, E. M.; SILVA, M. D. C.; PIETRO-SOUZA, W.; SILVA, T. J.; FARIAS, L. D. N. Efficiency of portable chlorophyll meters in assessing the nutritional status of wheat plants. Revista Brasileira de Engenharia Agrícola e Ambiental, v. 19, n. 12, p. 1148-1151, 2015.

SILVA, J. A. G.; GOI NETO, C. J.; FERNANDES, S. B.; MANTAI, R. D.; SCREMIN, O. B.; PRETTO, R. Nitrogen efficiency in oat on grain yield with stability. Revista Brasileira de Engenharia Agrícola e Ambiental, v. 20, n. 12, p. 1095-1100, 2016.

TEDESCO, M. J.; GIANELLO, C.; BISSANI, C. A.; BOHNEN, H.; VOLKWEISS, S. J. Análises de solo, plantas e outros materiais. Porto Alegre: Universidade Federal do Rio Grande do Sul, 1995.

THORNE, G. N.; WOOD, D. W. Effects of radiation and temperature on tiller survival, grain number and grain yield in winter wheat. Annals of Botany, v. 59, n. 4, p. 413-426, 1987.

UGARTE, C.; CALDERINI, D. F.; SLAFER, G. A. Grain weight and grain number responsiveness to pre-anthesis temperature in wheat, barley and triticale. Field Crops Research, v. 100, n. 2-3, p. 240-248, 2007.

ZHAO, B.; DUAN, A.; ATA-UL-KARIM, S. T.; LIU, Z.; CHEN, Z.; GONG, A.; ZHANG, J.; XIAO, J.; LIU, Z.; QIN, A.; NING, D. Exploring new spectral bands and vegetation indices for estimating nitrogen nutrition index of summer maize. European Journal of Agronomy, v. 93, n. 1, p. 113-125, 2018. 